\title{
An Experimental Approach for Studying the Fuel Characteristics of Agricultural Waste Based Charcoal A Case Study
}

\author{
B.Lonia, R.K.Bansal \\ Professor (Mechanical) CIET,Jalvehra,Fatehgarh Sahib \\ gurmani07@gmail.com \\ Associate Professor (Mechanical) CIET,Jalvehra, Fatehgarh Sahib \\ rk ravita@rediffmail.com
}

\begin{abstract}
This paper enlists fuel characteristics of agricultural wastes experimentally. Woody charcoal has been the primary fuel for cooking (power generation) in many countries because it is cheap and easily available .However, using wood charcoal has consequences on health and pollution because of smoking. This study aims at providing agricultural waste as an alternative to woody charcoal using agricultural based wastes (dry leaves, coffee husk, sugarcane trash, grass, etc) converted into charcoal briquettes to provide much needed source of cheap fuel that is cleaner in burning. The agriwaste, like rice-straw, saw-dust, sugarcane-trash, coir-pith, peanut -shells, wheat-stalks and straw, cotton-seed, stalks and husk, soybean stalks, maize stalks and cobs, sorghum, bagasse, waste wood, walnut shells, sunflower seeds, shells, hulls and kernels and coconut husk can be fruitfully utilized in power generation. This stuff is otherwise a waste and liability and consumes a lot of effort on its disposal; in addition to being a source of fire and health hazard. Apart from the above, it causes serious air pollution in the form of smoke, un-burnt suspended particles and unwanted addition of heat to atmosphere. Surely, agriwaste stuff at present is available in abundance and prospects of its utilization in producing energy are enormous. On the basis of calorific value, agri-residue is comparable with low quality coal.Manual extruder machine having a capacity of pressing $30 \mathrm{~kg} / \mathrm{hr}$ and the carbonizer converts $15 \mathrm{~kg}$ of input agricultural wastes into $5 \mathrm{~kg}$ of burned charcoal within 25 minutes. Power can be generated from $5 \mathrm{Kw}$ to $10 \mathrm{Kw}$ by using $10 \mathrm{~kg}$ of briquetted agricultural charcoal.
\end{abstract}

KEYWORDS:Agriwaste, Briquette, Charcoal, Coirpith, Kernaells, Extruder

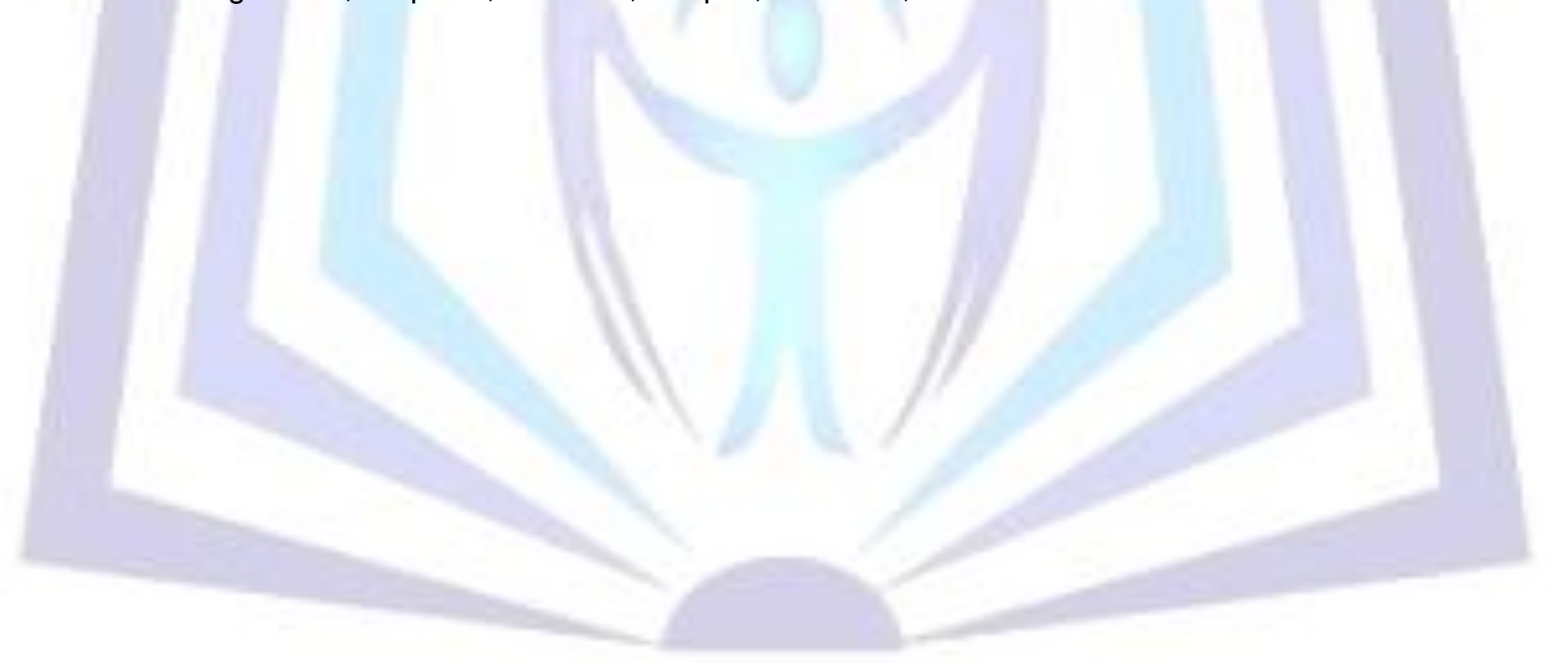

\section{Council for Innovative Research}

Peer Review Research Publishing System

Journal: International Journal of Management \& Information Technology

Vol. 5, No. 3

editor@cirworld.com

www.cirworld.com, member.cirworld.com 


\section{INTRODUCTION}

With the fossil fuels gradually depleting and hydro sources having reached the verge of full exploitation, we are compelled to think in terms of searching for and developing alternative sources of energy. Over the recent years, the problem of environment pollution, sustainability and safety have been added to the scene, calling for development of power generation systems which are techno economically viable, sustainable and safe. Several alternative sources of energy are being thought of, including the nuclear, solar, geothermal, wind, tidal and the biomass based. Keeping in view the three fold objective stated above viz. economic-viability, sustainability and safety, biomass as a source of energy holds a good and bright promise. In India, the use of biomass especially agriwaste is of particular interest and it may also lead to the environmental safety.

The large scale use of commercial energy has led to better quality of life; however it has also created many problems. Perhaps the most serious of these are the harmful effect on the environment and climate changes which both have consequences on human health and pollution. Also it is now clear that the fossil fuel era of non- renewable resources is gradually coming to an end, oil will be first to be depleted, followed by natural gas and coal. Energy problem is very serious and the main objective is now to find solution to match demand and supply of energy sources. It is already being used by the rural people as a major source of energy, mainly in cooking food, which constitutes almost over $90 \%$ of the total energy consumption (1). Assuming that the population of India is about 120 crore, $75 \%$ of the population in India lives in rural area (3), and assuming that each family consists of five persons and uses annually about 3 tons ofbiomass as fuel, one comes to the figure of about78 million tons of biomass utilized annually only for domestic cooking in rural areas only. The urban population of India (25\%) also uses biomass and assuming that $75 \%$ of the urban population uses this biomass as a fuel, one comes to the figure of 3.84 million tons of biomass as fuel. There is also a third dimension to fuel use, and that is the pollution arising due to burning of biomass. As cooking is done within the confines of a house, the pollution caused by cooking fires is generally not taken very seriously. But according to statistics published by the World Health Organization, annually about 500,000 women and children die prematurely in India due to air pollution caused by cooking fires in rural households (4). Considering the fact that almost $90 \%$ of our population is in rural areas, giving the rural women a cleanly burning biofuel is a major task. One way of tackling the pollution and health problems of the consumers of wood charcoal is producing briquette charcoal using agricultural wastes by making simple extruder and effective carbonizer.Agricultural waste is an ideal source of charcoal. When one harvests any crop, one generally harvests only grain, fruits, coffee, pods, and tubers. This constitutes only about 30 to $40 \%$ of the total biomass. This means that about 60 to $70 \%$ of the total agricultural biomass is the waste biomass produced annually in India. A small part of it is used as fodder for cattle, but the rest is just wasted. The produced char is healthy, environmentalfriendly and economical.

\section{SIGNIFICANCE OF THE RESEARCH}

Some of the benefits of using agricultural wastes, such as sugarcane trash, grass, and saw dust and so on, as an alternative cooking fuel are described as follows: Unlike wood, briquette charcoal is a smokeless fuel. The smoke produced by wood fires in an indoor cooking environment can lead to multiple respiratory illnesses $(5,6,7)$.Instead of burning agricultural wastes in the fields, using the wastes as a fuel source slows the advance of deforestation by eliminating the need to cut down trees for fuel wood. Charcoal is viewed as an advanced fuel in because of its clean-burning nature and the fact that it can be stored for long periods of time without degradation. Therefore, a micro- enterprise can be formed around the production of charcoal derived from agricultural waste. By turning something that was previously little used into a means by which to produce income, the wealth of individual entrepreneurs and the country in general is increased. Since it is a good technology, India also used charcoal produced from sugar cane trash (8).

The usage of energy from biomass, most commonly obtained through fire. The energy from agricultural waste biomass (crops, grass, residues, etc) can be harnessed through the process of combustion, which allows the material to be carbonized. Carbonization takes place when organic matter is raised to high temperatures in the absence of oxygen.

The following are main stages that exist in the biomass combustion process: The moisture embedded in the solid biomass must be removed before carbonization can take place. This can be achieved with drying prior to burning. If water remains, then the energy required to remove it is obtained by the burning of some of the biomass material inside the carbonizer itself. This decreases the amount of material that can be converted into useful charcoal. The biomass then undergoes pyrolysis, which is the chemical decomposition of organic matter in the absence of oxygen.Pyrolysis leads to carbonization of the materials. A high temperature is necessary for pyrolysis, but because agro-waste is both your fuel and the material that is being carbonized, a balance must be reached between the two objectives (creating heat and creating charcoal fines). Hence, air flow must be carefully restricted at the optimum time (when the proper temperature is reached, $270^{\circ} \mathrm{C}$ ) (9) so that the majority of agro- wastes remains unburned, ready to be converted into charcoal. It takes approximately $45 \mathrm{~min}-1 \mathrm{hr}$ to be turned to charcoal. Generally there is little study done here in Ethiopia on conversion of agro- wastes into charcoal and effect of wood charcoal on human health and pollution impact. This study aims at providing a biomass as an alternative to wood charcoal using agricultural wastes converted into charcoal briquettes to provide much needed source of cheap fuel that is cleaner in burning.

\section{OBJECTIVES OF THE RESEARCH}

This study aims at providing a biomass as an alternative to wood charcoal using agricultural wastes converted into charcoal briquettes to provide much needed source of cheap fuel that is cleaner in burning. It is also intended to create awareness of agricultural wastes briquettes technology and to make use of the technology by small scale. 


\section{MATERIALS AND METHODS}

Design consideration of the Charcoal carbonizer is a carbon substance that remains when organic matter is heated to a high temperature in a low-oxygen environment. It is designed and manufactured by the author that the carbonizer provides a means of creating this low-oxygen environment. The carbonizer is made of cylindrical oil drum with two conical shapes made of sheet metals that are welded at the bottom in such cases the upper part has 24 holes for removal of smokes and the lower one with no holes so the path of the smoke is upwards using the inserted cylindrical pipe at the middle of the carbonizer which is welded with the two conical shapes. Then it is covered at the top after inserting the dried agricultural wastes. The biomass is tightly packed into the inner drum and fired for 50 minutes to $1 \mathrm{hr}$ (depending upon the biomass material). In this method $40 \%$ of carbonized char can be obtained. Fig (1).

\subsection{Preparation of the binder}

The binder material is used for strengthening the briquettes and for every $30 \mathrm{~kg}$ of total weight of carbonized charcoal powder; prepare a binder mixture by adding 1.5 to $2 \mathrm{~kg}$ of a special mud and a little water based on the weight and type of the raw materials.

\subsection{Mixing}

Mixing should be such that every particle of carbonized charcoal material is coated with binder. It will enhance charcoal adhesion and produce identical briquettes. Fig.1. Carbonizer, Extruder and agro-wastes (grass, sugarcane trash, dry leaves, etc.) The charcoal extruder is designed and manufactured to make a small size of $30 \mathrm{~mm}$ diameter and produces eight briquetted charcoal at a time. The case and parts of the extruder are made from sheet metals and angle iron. To support the person while working with the extruder fly wheel made of concrete and sheet metal steel is added at free end of the extruder. The extruder is a screw type press, made of a sheet metal which is welded on a solid steel shaft, designed to produce high density briquettes. In this case, the raw material is mixed in a well and at the same time it is transported to the end of the extruder. Since the end of the extruder is a type of circular die with eight holes, the materials can be pressed against those holes to produce a compact and uniform size briquettes. The mixing time and rpm of the extruder depends on the person who works on the machine

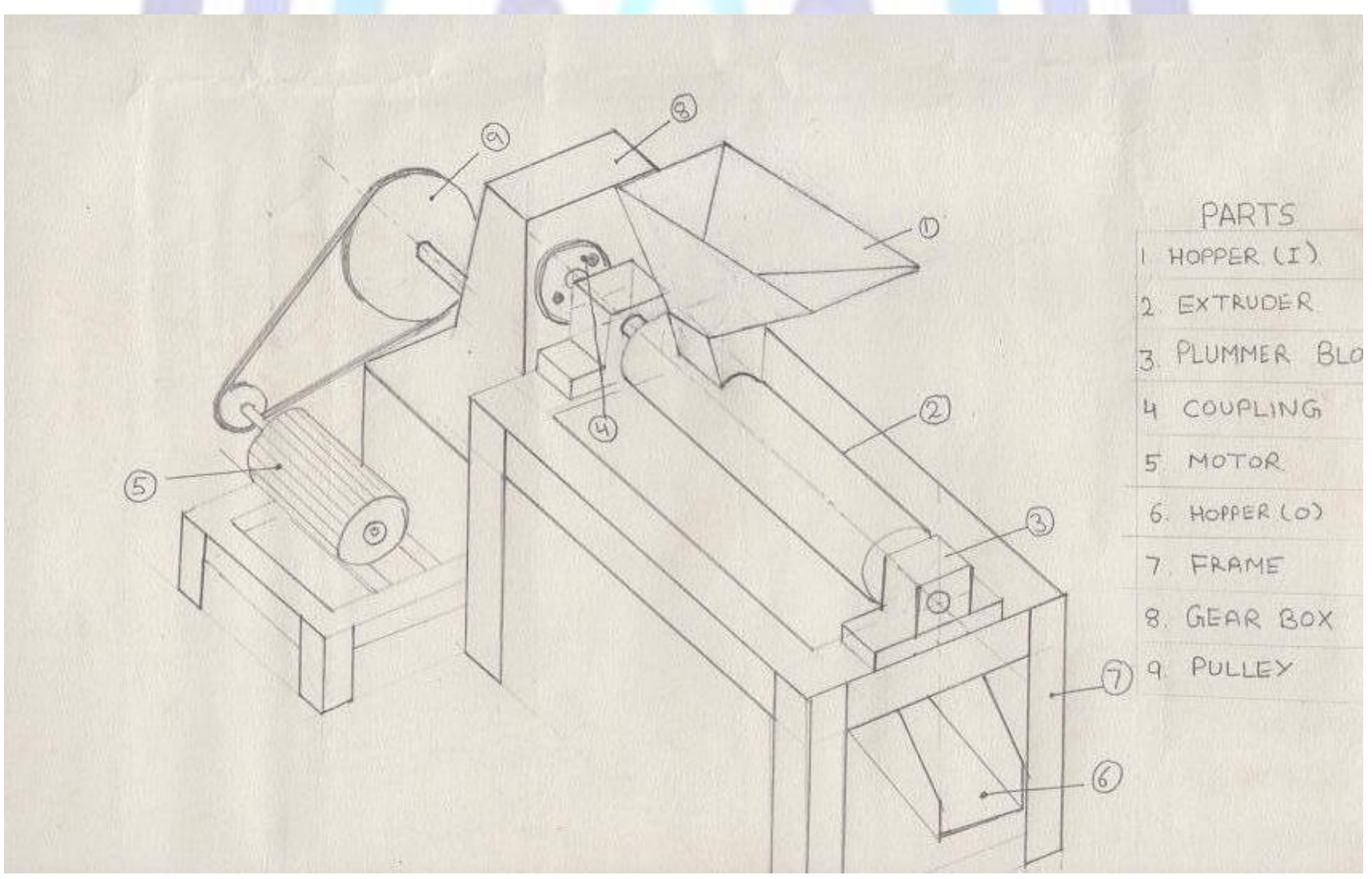

Fig.1Extruding machine with design condition and utilization of binder 


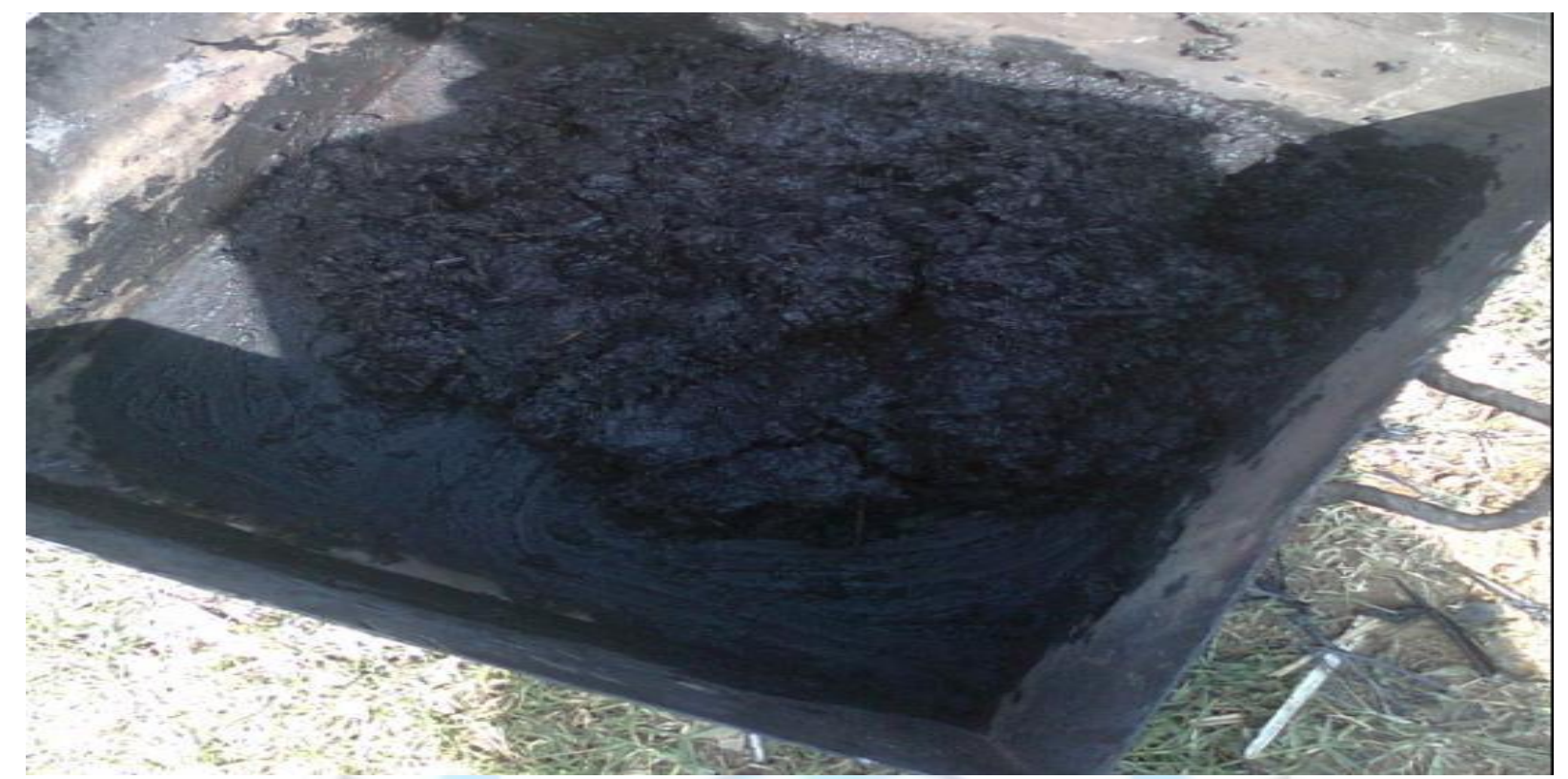

Fig.2.Carbonized charcoal mixed with the binder

\subsection{Briquetting}

Briquetting is one of several compaction technologies to form a product of higher bulk density, lower moisture content, and uniform size shape, and material properties. The charcoal mixture is made into briquettes using extruder machine. The extruder machine was constructed as part of this research work.

\subsection{Drying and packing}

The briquettes were collected in a tray dried under the sunlight for about 1-7 days, packed and sealed in plastic bags. The moisture must be removed by sun from the briquettes otherwise it is difficult for burning and reduces efficiency.

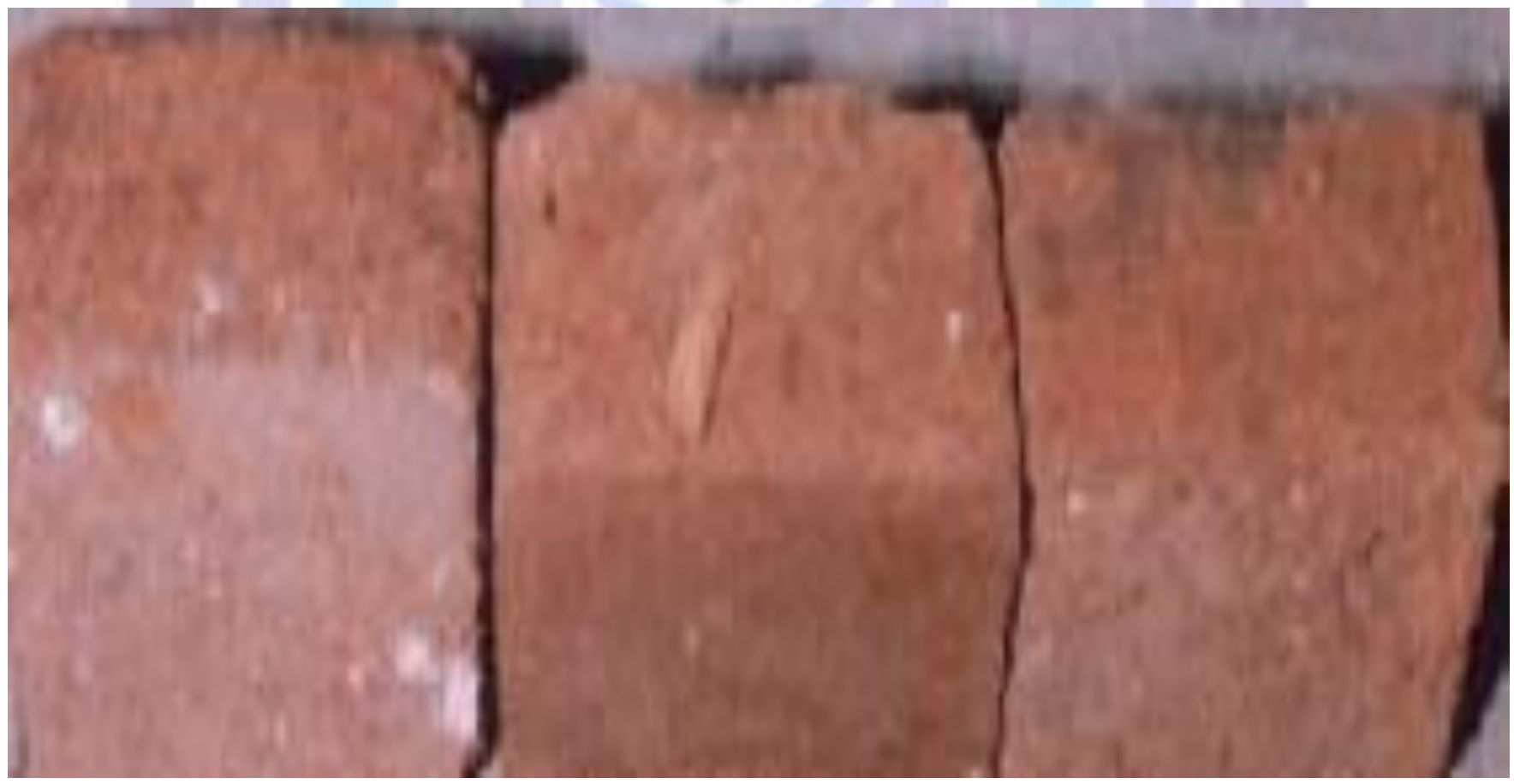

Briquttes before charcoal is made 


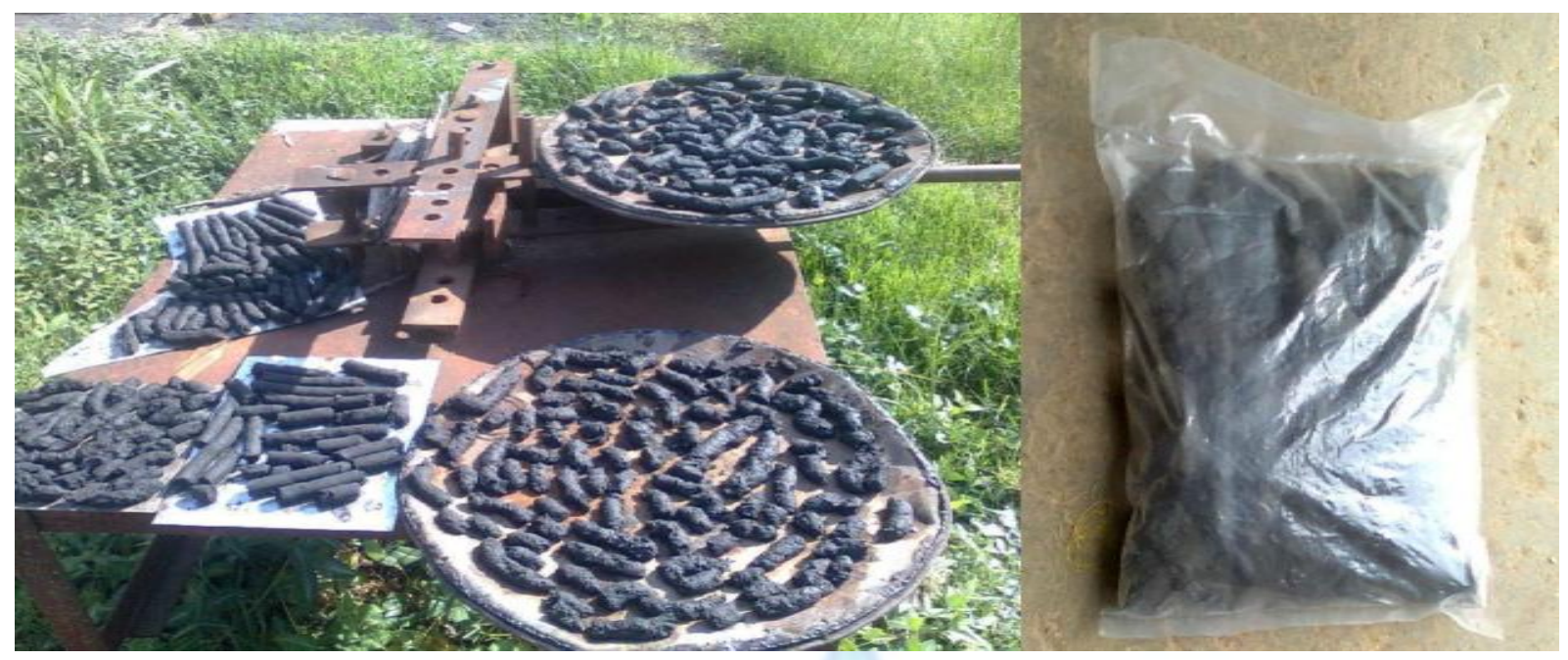

Fig.3. Drying

The firing system so adopted is a FBC system (Fluidized Bed Combustion System) enough briquettes were prepared.MC,

CV,AC and VC were calculated, which is shown in the table .1,1.1 shows the CV,MC\&AC of Composite fuels, 1.2 showsAvailability of Agricultural Residue in India,1.3 gives Agri Residue Estimates in North Zone\& Table1. 4 shows the Renewable Energy Potential in North India

Table. 1 The combustion parameters of the supplementary binders/fuels ((MC, AC, VC and CV

\begin{tabular}{|c|c|c|c|c|c|}
\hline S.No. & Material & MC \% & Ash \% & Volatile \% & $\begin{array}{l}\text { CV kJ/kg } \\
(\mathrm{kCal} / \mathrm{kg})\end{array}$ \\
\hline \multirow[t]{4}{*}{1.} & Leaves dried & & & & \\
\hline & Ashoka & $5-10$ & $2-3$ & 78.5 & 21840 (5200) \\
\hline & Shisham & $5-10$ & $2-5$ & 80 & $21000(5000)$ \\
\hline & Teak wood & $5-10$ & $2-8$ & 79 & 20790 (4950) \\
\hline 2 & Grass & $5-15$ & $2-5$ & 80 & $21210(5050)$ \\
\hline 3 & DOC & $5-10$ & $2-10$ & 82 & $22470(5350)$ \\
\hline 4 & Mallee & $5-12$ & $5-15$ & 78.2 & 20916 (4980) \\
\hline \multirow[t]{2}{*}{5} & Spentwash Liquid & - & & 60.0 & $12600(3000)$ \\
\hline & Spentwash dry & $5-8$ & $2-5$ & 83 & $22890(5450)$ \\
\hline 6 & Biowaste & $5-15$ & $5-15$ & 65 & $13400(3200)$ \\
\hline 7 & Bakelite Wash & $2-5$ & $2-3$ & 89.2 & $29400(7000)$ \\
\hline 8 & Twigs & 9.45 & 3.5 & 81.5 & $16800(4000)$ \\
\hline
\end{tabular}

*Waste from the distillery

** Productivity conditions have been taken constant in this study

As can be seen from the table volatile content of the seven materials except the biowaste is near or more than $75 \%$ which shows that the agriwaste has high volatile content which makes them fit to be used as fuel. In the subsequent experiments and studies these materials will be used in various combinations to get the appropriate fuels for power generation. 


\section{RESULTS}

The carbonizer was designed in order to produce $5 \mathrm{~kg}$ briquette charcoal from $15 \mathrm{~kg}$ of inputs (agricultural wastes, grass, sugarcane trash and dry leaves is used in this experiment) and burns for about 25minutes. The manual extruder has a capacity of pressing $30 \mathrm{~kg} / \mathrm{hr}$. The carbon content of briquette charcoal could be varied from $80 \%$ to as high as $82 \%$ or above by adjusting the carbonization condition, which depends on the amount and dryness of the input material to the Carbonizer.Since it loses its smoke inside the carbonizer during carbonization the briquette charcoal doesn't have smoke and burns cleanly due to very low sulfur content. The heating value of the briquette charcoal varies from 17,150 to 19,300 kcals with a density of $970 \mathrm{~kg} / \mathrm{m} 3$. Since it has a good heating value and higher density while briquetting it burns for about 2-3 hrs. The FBC system heat which can be used for power generation .

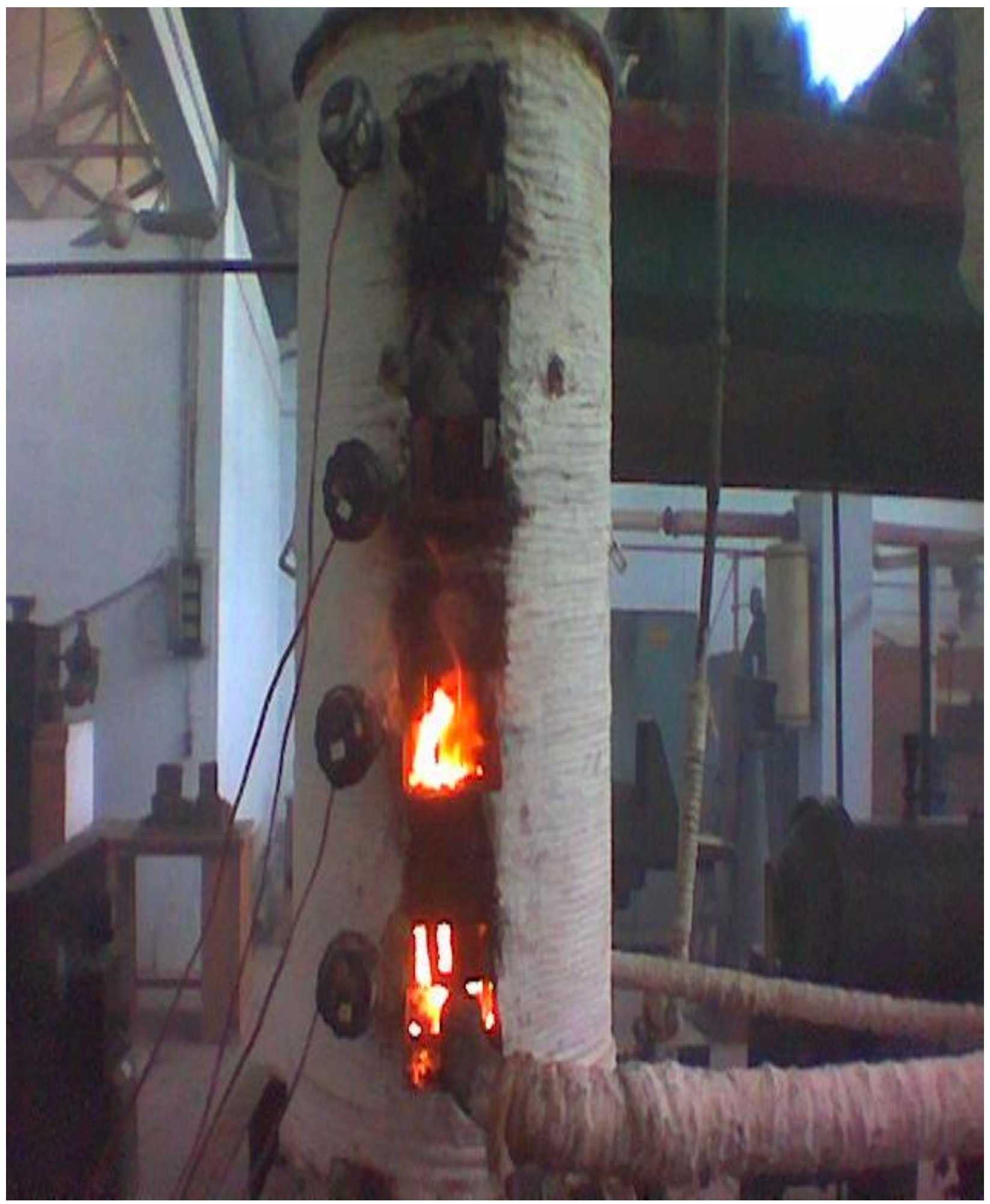

Figure:4 showing burning of briquettes 
Table -1.1 Calorific Value, Moisture Content \& Ash Content of Composite Fuels

\begin{tabular}{|c|c|c|c|c|c|}
\hline \multirow{2}{*}{$\begin{array}{c}\text { So } \\
\text { No }\end{array}$} & \multirow{2}{*}{ Multifuel } & \multicolumn{2}{|c|}{ Agri Charcoal CV } & \multirow{2}{*}{$\begin{array}{c}\text { Moisture Content } \\
\text { (\%age) }\end{array}$} & Ash Content (\%age) \\
\cline { 3 - 5 } & & $\mathbf{( M j / k g )}$ & $\mathbf{( k c a l / k g )}$ & 8.25 & 4.27 \\
\hline 1 & $\mathrm{MF}_{1}$ & 17.33 & 4126.2 & 7.8 & 5.88 \\
\hline 3 & $\mathrm{MF}_{2}$ & 17.00 & 4047.6 & 7.3 & 5.21 \\
\hline 4 & $\mathrm{MF}_{3}$ & 17.17 & 4088.1 & 8.06 & 6.58 \\
\hline 5 & $\mathrm{MF}_{4}$ & 17.10 & 4071.4 & 7.5 & 6.95 \\
\hline
\end{tabular}

The multi-fuel $\mathrm{MF}_{1}$ its highest calorific value and least ash content but it has maximum moisture content. The multi-fuel $\mathrm{MF}_{2}$ gives least calorific value.

Table1. 2 Availability of Agricultural Residue in India

\begin{tabular}{|l|c|c|c|}
\hline \multicolumn{1}{|c|}{ Type of Residues } & Energy Potential (MW) & $\begin{array}{c}\text { Quantity of Agriwaste } \\
\text { Required } \\
\text { (Million Tonnes) }\end{array}$ & $\begin{array}{c}\text { Available Agriwaste in } \\
\text { Northern Zone (Million } \\
\text { Tonnes) }\end{array}$ \\
\hline Agricultural residue & 9500 & 90 & 350 \\
\hline Agro-Industrial Residue & 9500 & 50 & 70 \\
\hline
\end{tabular}

Source: "Biomass Programme in India: An overview" NP Singh, MNES, New Delhi

Table1. 3 Agri Residue Estimates in North Zone

\begin{tabular}{|c|c|c|c|}
\hline Sr. No. & Agri-Residue & $\begin{array}{c}\text { Percentage Per } \\
\text { Acre } \\
\star \star\end{array}$ & $\begin{array}{c}\text { Quantity Available in } \\
\text { Northern Zone (Million } \\
\text { Tonnes) }\end{array}$ \\
\hline 1. & Wheat straw & $33.5^{\star}$ & 20.65 \\
\hline 2. & Rice husk & 12.0 & 8.16 \\
\hline 3. & Cotton stalks & 8.0 & 12.46 \\
\hline 4. & Sugarcane Bagasse & 32.0 & 12.88 \\
\hline 5. & Ragi\&Bajra straw & 77.0 & 15.00 \\
\hline 6. & Groundnut shells & 6.7 & 8.00 \\
\hline 7. & Maize & 50.0 & 12.00 \\
\hline
\end{tabular}

*These values depend upon the type and methods adopted.

Source ${ }^{\star *} R$ \& D requirements in Biomass combustion \& Gasification" O.P. Rao, CSIR, New Delhi 
Table1. 4 Renewable Energy Potential in North India

\begin{tabular}{|c|c|c|c|c|}
\hline $\begin{array}{l}\text { S. } \\
\text { No }\end{array}$ & Energy Sources & Country Potential & State Potential & Power generation Potential \\
\hline 1 & Biogas Plants & 12 Million (nos) & 424700(nos) & $164 \mathrm{MW}$ \\
\hline 2 & $\begin{array}{l}\text { Biomass (agri-residue, agro- } \\
\text { industrial waste \& energy } \\
\text { plantation) }\end{array}$ & $17000 \mathrm{MW}$ & $1000 \mathrm{MW}$ & $1000 \mathrm{MW}$ \\
\hline 3 & Small Hydro & $10,000 \mathrm{MW}$ & $140 \mathrm{MW}$ & $140 \mathrm{MW}$ \\
\hline 4 & Municipal Solid Waste & $\begin{array}{l}27.4 \text { Million } \\
\text { tones/yrs }\end{array}$ & 3.5 Million tones/yrs & $100 \mathrm{MW}$ \\
\hline 5 & Cogeneration (Sugar) & $5000 \mathrm{MW}$ & $140 \mathrm{MW}$ & $140 \mathrm{MW}$ \\
\hline 6 & Cogeneration (other industry) & $1000 \mathrm{MW}$ & $150 \mathrm{MW}$ & $150 \mathrm{MW}$ \\
\hline 7 & Solar Energy & $\begin{array}{l}5 \times 10^{15} \\
k \text { Wh/yr }\end{array}$ & $\begin{array}{c}2228.5 \\
\mathrm{k} W h / \mathrm{m}^{2} / \mathrm{yr}\end{array}$ & ----------- \\
\hline
\end{tabular}

\section{DISCUSSION}

The charcoal produced from agricultural wastes has more benefits from economical, health and environmental point of view. Implications on health .Unlike wood charcoal, this briquette charcoal are a smokeless fuel, due to the fact that during carbonization its smoke disappears. The smoke produced by wood charcoal fires in an indoor environment would lead to multiple respiratory illnesses $[6,7,8]$. It is also one means of getting rid of solid wastes which is hazardous for health. Normally some agro wastes can be used for various purposes, like as a fodder, compost or other purposes. But it is difficult to say that there is no agro wastes in India which can be left and used for briquetting process. It is possible to use almost all wastes for preparation of charcoal including waste sarkanda. The output of the charcoal can vary from one waste to the other. On the other hand, some solid agricultural wastes resists biodegradation and therefore cannot be used as a direct fertilizer. It can't be used as fodder, as it is highly indigestible. It is bulky and low density biomass, so it cannot be easily removed from the field, and also cannot be used as fuel. Chopped agricultural wastes cannot be used as a fuel directly, because it produces a lot of smoke. Also it requires a very high expenditure of energy to compress. On the other hand, it is well known that organic matter can be charred. The char briquettes are more efficient in burning with no smoke at all.

By burning agricultural wastes in the fields, using the wastes as a fuel source slows the advance of deforestation by eliminating the need to cut down trees for fuel wood. The other advantage is that since there is no smoke while burning, smoke pollution is reduced for the environment . The economy of Briquetted charcoal is viewed as an advanced fuel because of its clean burning nature and the fact it can be stored for long periods of time without degradation. Therefore, a micro enterprise can be formed. Any entrepreneur can create briquette from agricultural wastes and sell them in a local market for personal income. In this way, more money stays within the community rather than being exported for foreign fuels. By turning something that was previously unused into a means by which to produce income, the wealth of individual entrepreneurs and the country in general is increased.

\section{ECONOMIC FEASIBILITY}

The capital cost of the project is around Rs 98,000 thousand, this is to mean it is not difficult to start up with in a short period of time. In addition to that it is also not difficult to scale up the project in such a manner to spread the technology to every society.

\section{CONCLUSION AND RECOMMENDATIONS}

Till date agricultural wastes (grass, dry leaves, sugarcane trash, etc) which are produced in huge quantities had been put to little use. This research involves conversion of agricultural wastes to char, by an environment friendly, continuous batch process, briquetting of the char into a solid fuel form and use of an efficient, clean and user-friendly FBC system ideally suited for the briquettes as fuel. The techno-economic feasibility has been tested. The manufacturing technologies involved in each step are easy to implement in rural areas, and therefore it is also provides new income generating opportunities in rural parts. The technology has a great potential for converting waste biomass into a superior fuel for household use, in an affordable, efficient and environment- friendly manner. The above mentioned advantages is 
greater as compared to the open fire technique which is used for various purposes, like drying of seeds, removal of insects from the hut, etc in rural parts of India. The University should work hard towards disseminating this technology for society. Much more efforts must be made to establish the use these biomass resources and national research institutions should work hard in promoting and improving this briquetting technology.

\section{REFERENCES}

[1] Singh, T., "Effect of supply and return air outlets on energy consumption" with J.B. Olivieri, Ashrac Transactions, 1982, No. 2665, RP 217, Vol. 88, Pt. 1.

[2] Singh, T., "Rapid continuous Determination of Nitirc Oxide concentration in Exhaust Gases" Journal of air pollution control association, Vol. 18, pp: 102-105, 1968.

[3] Singh, Bimal, P., Panigrahi, M.R., Ray, H.S., "Review of agriwaste as a source of energy for India”, Energy sources, V22 n7 Aug. 2000 p.649-658.

[4] Singh, N.P., "Agriwasteprogramme in India: an overview" Proceedings of the International Conference, 2627 February 1996 (New Delhi), pp.65-72.

[5] Skrifvars, B-J., Blomquist, J-P., Hup, M., Backman, R., "Predicting the ash behavior during biomass combustion in FBC conditions by combining advanced fuel analyses with thermodynamic multi-component equilibrium calculations", presented at the $15^{\text {th }}$ annual International Pittsburgh Coal conference, Pittburgh, $\mathrm{Pa}$, USA, September 1998.

[6] Skrifvars, B-J., Zevenhoven, M., Backman, R., R. Ohman, M., Nordin, A., "Effect of fuel quality on the bed agglomeration tendency in a biomass fired fluidized bed boiler", Varmeforsk report No B8-803, ISSN 0282 3772, March 2000.

[7] Skrifvars, M., Zevenhoven, A.C., Hupa, Jenkins, B.M., "The ash chemistry in fluidized is gasification of biomass fuel, Par I-III, Submitted to Fuel.

[8] Splielhoff, H., Scheurer, W., Hein, K.R.G., "Effect of co-combustion of sewage sludge and agriwaste on emissions and heavy metals behaviour", UniversitiaetStruttgart, Stuttgart, Germany, Process safety and environmental protection : Transactions of the institution of chemical engineers, Part B, V78 n1, 2000, pp.33-39.

[9] Tranuik, Anncharlotte E.; Sanati, Mehri; Zethracus Bjorn; Lyberg, Mats, "Study of the bed fouling problems in a agriwaste fired commercial CFB boiler", The 1999 International Joint Power Generation Conference and ICOPE '99, Burlingame, CA, USA, 25-28 July 1999. American Society of Mechanical Engineers, Fuels and Combustion Technologies.

[10] Tripathi, A.K., lyer, P.V.R., Kandpal, T.C., "Questionnaire based survey of agriwaste briquetting in India", MNES, New Delhi, International Journal of Ambient Energy, V21 n1 Jan 2000. pp.31-40.

[11] Yokoyama, Shin-ya; Ogi, Tomoko; Nalampoon, Aman, "Agriwaste energy potential in Thailand”, Agriwaste and bioenergy, V18, n5, 2000, pp.405-410.

[12] Zevenhoven, M., Blomquist, J-P., Skrifvars, B-J., Backman, R., Hupa, M, "The prediction of behaviour of ashes from five different solid fuels in fluidized bed combustion, Fuel, Vol 79, 1353-1361-,2000.

[13] Zevenhoven, M., Skrifvars, B-J Yrjas, P., Hupa, M, Nuutinen, R., "Searching for improved characterization of ash forming matter in biomass", accepted for publication in the $16^{\text {th }}$ FBC Conference, to be held in May 2001. Remo, Nevada, USA.

[14] Zevenhoven-Onderwater, M.; Blomquist, J.P.; Skrifvars, B.J.; Backman, R.; Hupa, M., "Prediction of behaviour of ashes from five different solid fuels in fluidized bed combustion", Fuel, V79, n11, 2000, pp.1353-1361.

[15] Zhang, Bailiang, Li, Baoqian; Zhao, Chaohui; Xia, Zushang; Fu, Hantong "Application of BPB-1 biomass briquetting machine", TaiyangnengXuebao/ActaEnergiae Solaris Sinica, V20, n3, Jul. 1999, pp.234-238.

[16] Zhou, Jiachun; Masutani, Stephen M., Ishimura, Darren M., Turn, Scott. Q, Kinoshita, Charles M., "Release of fuel-bound nitrogen during agriwaste gasification", Industrial and Engineering Chemistry Research, V39, n3, 2000, pp.626-634.

[17] Zoelzer, K., "Advantages and disadvantages of fluidized bed illustrations for different applications", VGB Power Tech, V80, n1, 2000, pp.44-50.

[18] Sidhu, B.S., "Energy conservation and Management in Pump sets for irrigation" - a report on Energy audit, conservation and renewable energy conversion, July 15-Aug 5, 2002, pp. 111-115.

[19] Singh, Surendra, "Energy requirements, conservation and management in production agriculture" a report on Energy audit, conservation and renewable energy conversion, July 15-Aug 5, 2002, pp. 69-77. 
[20] Jain, A.k., "Biomass Characterization and utilization" a report on Energy audit, conservation and renewable energy conversion, July 15-Aug 5, 2002, pp. 27-34.

[21] Howard, J.R., "Fluidized Beds” M.H. Associates, Southall, U.K. pp. 89-112.

[22] Borislow Gruber, Dragoljub et al "Fluidized bed incineration tests of toxic liquid waste", paper NO. FB990121 - Proceedings of the $15^{\text {th }}$ International conference on fluidized bed combustion, May 16-19, 1999, Savannah Georgia.

[23] Bhatnagar, A.P., Soni, Rajesh, "Paddy Straw based power generation in Punjab - A report" Report No. SE-49/93, October, 1993.

[24] Grover, P.D., Mishra, S.K., "Regional Wood Energy Development Programme in India", Proceedings of International Workshop on Biomass Briquetting, New Delhi (India), April 3-6, 1995.

[25] Botterill, J.S.M., Toeman, Y. and Yurigir, K.R. Paper 2.4, Proceedings of XVIth ICMMT International Symposium Heat and Mass Transfer in Fixed and Fluidized beds, Dubrovnik, Yugoslavia, September 3-7, 1984.

[26] Wen, C/Y. and Yu, Y.H., AiChE., J., 1966, 12, 610.

[27] Zabrodsky, S.S., Antonishin, N.V. and Parnas, A.L. Can. J. Chem. Engg. 1976, 54, 52.S

[28] ShubhenKapila, Virgil Flanigan, Honglan Shi etal "Fluidized bed combustor for treatment of waste from livestock operations" Proceeding -waste research Technology -2002. Centre for Environmental Science and technology, University of Missouri- Rolla.

[29] Hamdy. A .TAHA "Tora Optimization Systems-2004

[30] 30. Lonia, B; Nayar, n.k\& Bali, P.L," Power from Agri-waste: Prospects, Problemsand ways out", Engineering today, Vol-4, Issue-6,PP 1-11.

\section{Authors Biography}

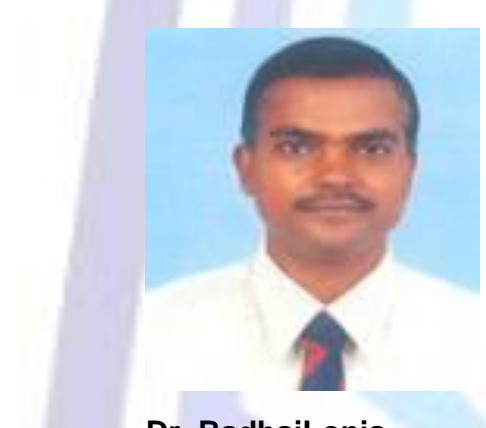

\section{Dr. BadhaiLonia}

BE- Mech, ME- heat Power, PhD. -Thermal Engineering - all Degrees from Thapar University - Patiala.

Published - 65 papares in National, International Journals and Conferences .Carried out -10 projects at National Level .Published -01 Book, Undertaken PhD. Research Guidance -04, ME Guidance - 04. Consultancy projects -07 .

\section{Dr. BadhaiLonia}

